\title{
Mujeres privadas de libertad en la cobertura noticiosa. Consecuencias sociales tras la publicación de sus casos judiciales
}

\author{
Women deprived of freedom in news coverage. \\ Social consequences after the publication of their judicial cases. \\ Mag. Karol Ramírez Chinchilla \\ Universidad Estatal a Distancia, Costa Rica
}

Resumen. El objetivo principal de la investigación fue comprender la forma en la que son afectadas las mujeres privadas de libertad del Centro de Atención Institucional Vilma Curling Rivera $^{2}$, después de las informaciones que publicó la prensa escrita costarricense sobre sus propios casos judiciales. Para ello, se empleó una metodología de enfoque cualitativo, de tipo exploratorio y descriptivo para privilegiar la recolección de información y generar el intercambio de opiniones entre la población recluida, a partir de las experiencias que ellas tuvieron frente a los medios de comunicación escrita. Debido a la ausencia de investigaciones similares, este estudio busca brindar aportes teóricos y prácticos a la cobertura informativa referente a las mujeres privadas de libertad, desde la perspectiva de un periodismo que cumpla con su función social. Las conclusiones apuntan a la necesidad de instaurar en el país la figura del Defensor del Lector -tal como lo hizo en 1992 el diario japonés Asahi Shimbun-, en aras de garantizar un periodismo social, así como la importancia de ejecutar procesos de capacitación y sensibilización para el abordaje periodístico, con el fin coadyuvar a una verdadera reinserción en la sociedad, evitando estereotipos, estigmas y etiquetas sociales que afecten su desarrollo.

Palabras clave: privadas de libertad, prensa escrita, inserción social

\begin{abstract}
The main objective of the investigation was to understand the way in which women deprived of liberty of the Vilma Curling Rivera Institutional Care Center are affected, following the information published by the Costa Rican written press about their own judicial cases. For this, a qualitative, exploratory and descriptive approach methodology was used for the collection of information and to generate the exchange of opinions among the incarcerated population, based on the experiences they had with the written media. Due to the absence of similar research, this study seeks to provide theoretical and practical contributions to information coverage regarding women deprived of liberty, from the perspective of a journalism that fulfills its social function. Conclusions point to the need to establish in the country the figure of the Ombudsman - as did the Japanese newspaper Asahi Shimbun in 1992 - in order to guarantee social journalism, as well as the importance of carrying out training and awareness processes. for the journalistic approach, in order to contribute to a true reintegration of those women into society, avoiding stereotypes, stigmas and social labels that affect its development.
\end{abstract}

Key words: women prisoners, media written communication, social reintegration

\footnotetext{
${ }^{1}$ Periodista con maestría en Comunicación y Desarrollo. Comunicadora social en la Universidad Estatal a Distancia, Costa Rica. Dirección electrónica: kramirezcr@uned.ac.cr

${ }^{2}$ El centro penitenciario, en el momento del estudio, era llamado El Buen Pastor. Este artículo acogerá el nombre actual "Vilma Curling Rivera", a fin de exponer una mejor referencia.
} 


\section{Introducción}

Es importante hoy hablar de mujeres; pero mujeres privadas de su libertad: mujeres hijas, madres, esposas y jefas de hogar que aun dentro de las cárceles siguen sosteniendo los lazos que las atan a los roles que la sociedad misma les ha impuesto por ser mujeres. Tras las rejas, ellas siguen pensando en sus hijos, en sus familias $y$ en sus obligaciones como organizadoras del hogar, en medio de sus inquietudes acerca de su futuro una vez que salgan de prisión.

Históricamente, el rol de la mujer ha sido clave para la conformación de la sociedad patriarcal y al tipo de familia que responda a esta colectividad; a la mujer le ha correspondido la organización de la vida cotidiana, la reproducción y el cuidado de la familia y los enfermos, en un contexto social marcado por la supremacía masculina atribuida a la fuerza física, al poder y a la división sexual en torno al trabajo.

En tal contexto, las mujeres que delinquen y llegan a perder su libertad reciben una condena social por haber abandonado aquellas tareas a las que fueron llamadas. De la misma manera, aquellas que en el delito infringen la norma social relacionada con el llamado de la maternidad, son también castigadas en prisión por sus similares, alimentadas por los mensajes mediáticos que han consumido durante los pocos espacios que tienen para relacionarse con los medios de comunicación.

Las características socioculturales asumidas por su género, más las condiciones que cada día las acompañan en los módulos de los centros penales y los procesos judiciales que antecedieron a su llegada a las celdas, lanzan mensajes que son consumidos por el público externo e interno, como sujetos críticos y capaces de construir representaciones de sus iguales y generar percepciones acerca de ellos.

Estas mujeres requieren que la sociedad esté dispuesta a recibirlas con tolerancia una vez dejen el penal. Dentro o fuera de la cárcel, ellas mantienen un vínculo innegable con su círculo social y, en su privación de libertad, resulta de gran importancia para su proceso de adaptación social el mensaje que la prensa escrita emite acerca de ellas. Dicho mensaje incluye, además del discurso, las imágenes, que presentan una doble lectura: una que refleja la realidad y otra que influye en los destinatarios de su mensaje. Una imagen puede mostrar la realidad y también distorsionarla si exalta una parte por encima del todo, lo que genera estereotipos (Genara, 2009).

Se parte, entonces, del hecho de que la publicación de informaciones acerca de las mujeres privadas de libertad, es considerada como un producto de consumo, que puede representarlas ante una audiencia que, al adueñarse de los contenidos, reacciona con indiferencia, identificación, rechazo o solidaridad, entre otros sentimientos.

García y Martínez (2008) señalan, precisamente, que reconocer el papel activo de las receptoras y los receptores permitirá comprender el significado que las audiencias le otorgan a la representación de género en los medios de comunicación. Agregan que dicha teoría, apegada al proceso de significación, se justifica si se asume que los medios funcionan como agujas hipodérmicas que inyectan significaciones, representaciones e imaginarios y que en este proceso las audiencias solo participan como simples vasos contenedores (Martín Barbero, 1987; Orozco, 1987; Canclini, 2002). 
La presente investigación se propuso como objetivo general comprender la forma en la que las informaciones acerca del tema carcelario, publicadas por la prensa escrita costarricense, intervienen en el entorno de las mujeres privadas de libertad del Centro Atención Institucional Vilma Curling Rivera.

Tanto en su pregunta de investigación: ¿cómo intervienen las informaciones publicadas por la prensa escrita costarricense, acerca del tema carcelario, en el entorno y desenvolvimiento de las mujeres privadas de libertad del Centro de Atención Institucional Vilma Curling Rivera?, como en sus objetivos, el presente estudio toma a las mujeres privadas de libertad cuales actoras para determinar la forma en la que ellas son afectadas en su entorno por las informaciones que publica la prensa escrita sobre sus propios casos.

El estudio se completa con objetivos específicos que buscan:

1. Describir el abordaje periodístico que hace la prensa escrita costarricense de sucesos relacionados con mujeres privadas de libertad.

2. Conocer la forma en la que las mujeres privadas de libertad leen el discurso que genera la prensa escrita acerca de ellas.

3. Explorar la forma en la cual este discurso les afecta en lo privado y en lo público, en su desenvolvimiento en los centros carcelarios.

4. Conocer la forma en la cual influye el fenómeno de la prensa escrita en la autoimagen que tienen de sí mismas las mujeres privadas de libertad.

5. Brindar aportes teóricos y prácticos a la cobertura informativa referente a las mujeres privadas de libertad, desde la perspectiva de un periodismo que cumpla con su función social.

\section{Metodología del estudio}

Partiendo de sus propias percepciones, se busca presentar resultados acerca del ejercicio periodístico: por ende, se toma una metodología de carácter cualitativo, que utiliza la técnica de cuestionario de preguntas cerradas y abiertas para lograr la descripción de los hechos que interesan conocerse de las personas participantes.

Así, el estudio es de enfoque cualitativo, de tipo exploratorio y descriptivo. Con la incorporación de técnicas descriptivas, se buscó privilegiar la recolección de información en aras de generar el intercambio de opiniones entre la población recluida, a partir de las experiencias que ellas han tenido frente a los medios de comunicación escrita.

La investigación es exploratoria: por lo tanto, desde el campo de la comunicación, se emplea una metodología de análisis de las informaciones publicadas en relación con ellas, desde la construcción periodística y gráfica de la información, sin aplicar un análisis de discurso tal cual se concibe. De esta forma, se analiza una pequeña muestra de las informaciones según sea su presentación gráfica, palabras usadas, títulos y cuerpo de la nota, así como la frecuencia con la que fue publicada en los medios de comunicación escrita. Al ahondar en este constructo, es posible establecer una comparación entre las partes involucradas en la investigación: mujeres privadas de libertad y prensa escrita.

En esta investigación, se emplea el método etnográfico en tanto utiliza la observación y entrevistas semiestructuradas a profundidad como medios para captar el significado de la comunicación al analizar 
las percepciones y compartir actividades con ellas. Para ello, fueron realizadas al menos tres visitas al centro penal, a fin de observar su desenvolvimiento con sus compañeras, sus actividades y su relación con diferentes personas en su entorno.

Los datos que se presentan fueron obtenidos en las actividades realizadas entre el 2013 y el 2014, periodo que marcó a la opinión pública con casos de mujeres que ocuparon los medios por delitos contra la vida, tráfico de estupefacientes y negocios familiares ilegales. Así las cosas, se trabajó con un grupo de mujeres privadas de libertad recluidas en dicho centro penitenciario, con la característica en común de formar parte del Programa de Atención a Privados de Libertad, de la Universidad Estatal a Distancia (UNED), por razones de facilidad para la investigación en cuanto a los permisos penitenciarios de trabajo dentro del penal.

Con ellas fueron realizadas entrevistas personales y trabajos grupales, a partir de sus propias experiencias con la prensa escrita nacional y de las informaciones publicadas acerca de cárceles y poblaciones penitenciarias, previamente identificadas en los periódicos nacionales mediante mecanismos de búsqueda por palabras claves como: cárcel, prisión y privadas de libertad.

La selección del grupo de mujeres se realizó siguiendo criterios de noticiabilidad de su caso, tomando como parámetro la publicación de su detención, procesamiento penal y reclusión, siempre dentro del grupo de mujeres seleccionado por facilidad de permisos para la investigación; además, con la premisa de que sería más sencillo trabajar con ellas, que estaban ya inmersas dentro de un círculo académico como estudiantes universitarias. De esta forma, podrían entender con más facilidad los aportes que, desde la academia, podrían realizarse para el mejoramiento del ejercicio periodístico en este tipo de coberturas de nota roja y para el fortalecimiento de sus procesos de inserción.

Es preciso señalar que para esta investigación se obtuvo la autorización, por parte del Ministerio de Justicia y Paz, para trabajar únicamente con cuatro mujeres privadas de libertad dentro de este grupo de estudiantes. Esta decisión obedece a las medidas de seguridad adoptadas en la Dirección General de Adaptación Social para resguardar los ambientes penales $\mathrm{y}$, además, a la gran cantidad de solicitudes de investigación relacionadas específicamente con esta institución carcelaria.

Como primer paso para el desarrollo del estudio, se realizó una revisión bibliográfica para conocer el estado de la cuestión respecto a la construcción de estereotipos y representaciones sociales de género, al igual que del ejercicio periodístico en la nota de sucesos, y así asumir perspectivas teóricas pertinentes con el objeto de estudio. Lo anterior incluyó la revisión de:

- libros relacionados con la comunicación y derechos humanos,

- trabajos finales de graduación en bibliotecas universitarias,

- artículos indexados afines,

- ponencias o conferencias relacionadas con el tema en cuestión,

- artículos de prensa escrita relacionados con el tema carcelario (cobertura de sucesos), tomando a los principales medios de circulación nacional: $L a$ Nación, La República, Diario Extra, CRHoy y La Prensa Libre.

En la búsqueda realizada en las fuentes mencionadas anteriormente se emplearon palabras claves como: comunicación, periodismo, sucesos, prensa, noticia, cárceles, privadas de libertad, centros penales, centros penitenciarios, derechos humanos, estereotipos y sociedad.

Un segundo paso consistió en determinar los medios de comunicación escrita con 
los que se trabajaría en función del objetivo específico 1 , que se relaciona con la descripción del trabajo de la prensa en la cobertura de sucesos de Costa Rica. Para ello, se desarrolló una revisión de los principales medios de comunicación impresa en este país para conocer cuánta cobertura al tema de sucesos daban en sus ediciones regulares.

Con la información recabada, se realizó el procesamiento teórico para determinar su pertinencia y la forma en la que serán aprovechados como elementos enriquecedores del proceso de construcción. Se extrajeron, además, aquellos datos que puedan ser representados gráficamente y los que requieren un tratamiento especial, como por ejemplo las imágenes.

Las mujeres seleccionadas para la investigación fueron informadas acerca de los objetivos del estudio, sus alcances y su metodología. Posteriormente, se les solicitó su autorización para utilizar la información personal con fines investigativos, según se señala en el Reglamento Ético Científico de la Universidad de Costa Rica (UCR) para las investigaciones en las que participan seres humanos.

Luego, se realizaron las entrevistas personales semiestructuradas y a profundidad según cada caso, en el marco de un trabajo de grupo que permitió más apertura para el diálogo, al sentirse acuerpadas unas con otras.

Las entrevistas para la población en estudio abordaron temas de interés para la investigación, como, por ejemplo: las experiencias relacionadas con la prensa escrita, la convivencia en el penal y las relaciones que giran alrededor del trabajo que hace la prensa.

Estas tuvieron una estructura tal que permitió la identificación (cómo se identifican las reclusas), su expresión (cómo reproducen lo consumido en la prensa) y su significación (valores de significación encontrados en el ejercicio de la prensa y su situación).

Asimismo, incluyó preguntas vinculadas a su experiencia con la prensa escrita en la cobertura periodística de su caso, también en su detención, juicio y traslado al centro penal, delito que cometieron, condena que cumplen, informaciones publicadas de ellas mismas, reacciones de sus familiares y repercusiones de las informaciones publicadas.

Con esta herramienta, se facilitó la posibilidad de hacer preguntas que fomenten el diálogo dirigido hacia los objetivos de la investigación, lo que permitió ahondar con más detalle en las experiencias que cada una de las mujeres enfrentó como consecuencia del delito cometido, en relación con su exposición en la prensa escrita costarricense.

\section{Resultados}

Para la mayoría de medios de comunicación convencionales, las informaciones de sucesos se han convertido en material de fácil acceso y de elevada rentabilidad, ya que suelen observar un aumento en sus niveles de rating y pueden a su vez llenar espacios valiosos de sus ediciones informativas. $\mathrm{La}$ cobertura de tales informaciones se ha convertido para los profesionales en comunicación en una batalla campal por quién logra llegar de primero a la noticia. Una vez adquirida, la nota es desarrollada y emitida una y otra vez, en razón del argumento de la demanda que la misma audiencia pide de ella.

El ejercicio del periodismo funcionalista cumple las acciones básicas de informar, interpretar, formar y entretener. En ese cumplimiento de funciones, concentra un amplio campo de acción que se divide en secciones como: actualidad, espectáculos, 
cultura, deportes, sucesos y otras. En la cobertura de sucesos, la premisa parte del hecho de que las llamadas malas noticias son siempre noticia. Por lo tanto, recoge temas como homicidios, suicidios, robos, accidentes de tránsito, catástrofes naturales y dramas humanos.

La (el) periodista cumplen en la sociedad una labor fundamental, pues es llamado a facilitar información oportuna y veraz. Tiene, entonces, una importante responsabilidad social, dado que sus mensajes tendrán el poder de transformar los procesos cognitivos de su público receptor. Socialmente, a los(as) periodistas se les ha conferido un lugar predominante en la construcción social de significados, otorgándoles un poder y una credibilidad inquebrantables. Lo que diga o escriba un(a) periodista es tomado como cierto, verdadero, incuestionable.

Desde el lado mismo de persona periodista, cualquier acontecimiento puede convertirse en noticia, pues su facilidad de difusión y la credibilidad puesta en sus manos le dan el poder suficiente para "inyectar" en la mente de sus receptores una verdad absoluta, que es asumida casi que sin objeciones por un público que confía en el trabajo de tales profesionales.

Existe claro un público crítico capaz de disentir respecto de lo que es noticia; sin embargo, la ventaja que tienen los medios de programar la agenda noticiosa en una sociedad receta para todos por igual un panorama que es difícil de evitar, si se está siempre en contacto con los medios de comunicación social para permanecer conectado con la realidad del país y del mundo en el que se vive. Por ende, el tema que atrapa la agenda mediática se convierte en noticia, lo quiera el público o no. Con desagrado o sin este, el (la) receptor(a) termina consumiendo ese temario noticioso que los medios de comunicación preparan en sus diferentes ediciones.

Cuadro 1 Cantidad de notas periodísticas publicadas en el 2013 acerca de cárceles en La Nación, Diario Extra y CRHoy.

\begin{tabular}{|l|l|l|}
\hline La Nación & Diario Extra & CRHoy \\
\hline 213 & 222 & 245 \\
\hline
\end{tabular}

Fuente: Elaboración propia (2016) con base en monitoreo de los tres medios de comunicación.

Durante el 2013, La Nación, Diario Extra y el portal digital $C R H o y$ publicaron en total 680 informaciones relacionadas con cárceles, privados de libertad o prisiones, con hechos acaecidos en el ámbito nacional e internacional, como se observa en el Cuadro 1.

Así las cosas, cada uno de ellos publicó más de 200 notas acerca del tema carcelario. CRHoy se presenta como el medio que más noticias relacionadas con cárceles emitió durante el 2013, con 245 artículos. Al analizar la frecuencia con la que cada medio publicó las informaciones, se deduce que CRHoy publicó una nota relacionada con el tema cada 0,67 días, seguido de Diario Extra cada 0,61 días y $L a$ Nación cada 0,58 días.

Aunque no es posible establecer un análisis comparativo entre los tres medios, debido a que dos de ellos imprimen sus ejemplares y uno de ellos se encuentra en la web, sí se puede concluir que el sitio digital CRHoy fue el medio que tuvo más publicaciones de sucesos durante el periodo de análisis. Esto podría relacionarse con la alta actualización que 
acompaña a un medio digital, en el cual la información debe ser inmediata $\mathrm{y}$ presentarse a un clic para el lector.

Esta actualización constante que requiere el medio en la web le hace disponer de más recursos, personal y mejores políticas periodísticas para desarrollar el correspondiente seguimiento de los acontecimientos. A CRHoy le siguen Diario Extra y, en un último lugar, se observa al periódico La Nación, un diario enfocado más a temas políticos, económicos, culturales y deportivos.

Para un medio cuyo fuerte es llevar la nota periodística en físico a su lector, existe un proceso distinto de impresión de ejemplares que resta inmediatez. Además, le hace encontrarse con su consumidor final un día después de ocurrido el suceso.

Es fundamental agregar que los sucesos son hechos fortuitos que alteran el orden normal de lo cotidiano: por consiguiente, su frecuencia es mayor que la cobertura habitual de acontecimientos en temas país, salud, economía y educación, entre otros

Asimismo, la frecuencia también se relaciona con el seguimiento del suceso, según sea el impacto que este hecho haya generado en la audiencia. En ocasiones, dicho seguimiento se mantiene incluso por varios días en sus principales ediciones informativas, ocupando un espacio significativo dentro del menú noticioso.

De las informaciones analizadas en la revisión, se extrajeron al azar 20 títulos que representan $40 \%$ de los contenidos, con la finalidad de construir una imagen que permita identificar los contenidos que emplea la prensa al abordar los temas relacionados con la privación de la libertad y los sujetos (especialmente mujeres) que experimentan esa condición. Lo anterior, se observa a continuación, en el Cuadro 2:

Cuadro 2 Análisis de contenidos y referencias de los principales titulares publicados en el 2013 por La Nación, Diario Extra y CRHoy

\begin{tabular}{|l|l|}
\hline Contenidos & Referencialidades \\
\hline $\begin{array}{l}\text { Motines agresiones } \\
\text { Mafarranchos }\end{array}$ & $\begin{array}{l}\text { Acciones que propician los privados de } \\
\text { libertad para ejercer presión contra las } \\
\text { autoridades. Con estas frases, los periodistas } \\
\text { Automutilación } \\
\text { Gresca } \\
\text { Problemáticos }\end{array}$ \\
$\begin{array}{l}\text { inten retratar la violencia y el descontrol } \\
\text { que, aparentemente, ocurren en los centros } \\
\text { penales, que en cierta medida identifica a las } \\
\text { personas privadas de libertad, en tanto } \\
\text { actores de los hechos. }\end{array}$ \\
$\begin{array}{l}\text { La utilización de estas frases o palabras } \\
\text { evidencian por sí solas la gravedad de los } \\
\text { hechos, que al ser descritos con palabras } \\
\text { propias del argot popular transmiten } \\
\text { conceptos más cercanos y reales, provocando } \\
\text { sentimientos de rechazo. }\end{array}$ \\
\hline
\end{tabular}


Matan para no pagarle deuda Intimidación y tortura Son quemados y golpeados por otros reos Mataron 32 personas en 2 años Matar

Color de hormiga

Reos

Menores presos

Presos

Convictos

Asaltantes

Reclusas

Puñales

Gallo pinto

Droga

Litro de Cacique

Defensoría

Premian gatos

Sed de venganza social
Situaciones que se registran en las cárceles que evidencian en cierta forma el grado de criminalidad y violencia dentro de instituciones hechas para la readaptación de las personas que cometen un delito en la sociedad.

Evidencian también de alguna manera la vulnerabilidad de las medidas de seguridad impuestas por las autoridades para mantener el orden y el control en la población privada de libertad.

Alusión a la intensidad de la situación, con el empleo del color rojo, atribuyendo a la situación la simbología de peligro asignada a ese tono.

En otras connotaciones, hace alusión a lo negro que puede verse el panorama, tomando al color negro como una simbología que advierte un hecho malo, feo sombrío u oscuro.

Palabras con las que comúnmente se identifica a las personas privadas de libertad. En algunas ocasiones, se utilizan como sinónimos palabras que los ligan con la criminalidad y la delincuencia.

Artículos que la prensa señala que existen dentro de los penales a pesar de la revisión exhaustiva al ingreso de los centros penales. Estos artículos les sirven de intercambio a la población privada de libertad para delinquir dentro de las instituciones carcelarias.

Institución que ha fungido como garante del cumplimiento de los derechos humanos dentro de las cárceles. Se señalan las condiciones de insalubridad y hacinamiento en las que vive la población privada de libertad.

Animales utilizados por los privados de libertad para el trasiego de droga o dinero entre ellos mismos.

Refiere a los pensamientos que podrían acompañar a las personas privadas de libertad, una vez que salgan de prisión para cobrar los días de reclusión en condiciones no aptas. 


\begin{tabular}{|c|c|}
\hline Hierro prensado & $\begin{array}{l}\text { Nombre con el que se conoce a los puñales } \\
\text { que son ocultos en medio de las nalgas de los } \\
\text { privados de libertad para resguardar su } \\
\text { seguridad o defenderse de los otros. }\end{array}$ \\
\hline $\begin{array}{l}\text { Dejar cárceles } \\
\text { Reos recién salidos de prisión } \\
\text { Indulto } \\
\text { Regalan } \\
\text { Mujer indultada }\end{array}$ & $\begin{array}{l}\text { El fin último que persigue todo privado de } \\
\text { libertad, ya sea después del cumplimiento de } \\
\text { su condena o mediante el otorgamiento de un } \\
\text { indulto presidencial, considerado un regalo } \\
\text { para ellos. }\end{array}$ \\
\hline Falta de seguridad & $\begin{array}{l}\text { Señalamiento que se hace a las cárceles ante } \\
\text { el registro de incidentes en dichas } \\
\text { instituciones. }\end{array}$ \\
\hline Jueces penales & $\begin{array}{l}\text { Dictan las sentencias contra los privados de } \\
\text { libertad y son considerados expertos en } \\
\text { materia de criminalidad e inseguridad. Por su } \\
\text { vinculación en el proceso penal de los } \\
\text { privados de libertad, son también } \\
\text { considerados por muchos como enemigos o } \\
\text { culpables de su suerte. }\end{array}$ \\
\hline Visitar cárceles & $\begin{array}{l}\text { La visita a la cárcel es considerada una } \\
\text { experiencia dolorosa o peligrosa para } \\
\text { personas externas, debido a las diferentes } \\
\text { situaciones que allí se presentan. }\end{array}$ \\
\hline Asesinados & $\begin{array}{l}\text { Situación a la que afirman llegan algunos } \\
\text { privados de libertad al salir de la cárcel, } \\
\text { debido a diferentes motivos. }\end{array}$ \\
\hline Libertad & $\begin{array}{l}\text { Condición anhelada por la población privada } \\
\text { de libertad. }\end{array}$ \\
\hline Hacinamiento & $\begin{array}{l}\text { Se refiere a la cantidad de personas privadas } \\
\text { de libertad que viven en espacios reducidos y } \\
\text { limitados para albergarles, provocando } \\
\text { condiciones infrahumanas. }\end{array}$ \\
\hline Día de la Madre & $\begin{array}{l}\text { Celebración que toca las fibras más livianas } \\
\text { del ser humano; por lo tanto, ha sido una } \\
\text { fecha seleccionada para el otorgamiento de } \\
\text { indultos a la población femenina privada de } \\
\text { libertad, en un juego de sentimientos y } \\
\text { emociones. }\end{array}$ \\
\hline $\begin{array}{l}\text { Vilma Curling Rivera } \\
\text { Cárcel } \\
\text { Cárceles } \\
\text { Juveniles cárceles }\end{array}$ & $\begin{array}{l}\text { Instituciones que contribuyen a la } \\
\text { readaptación de las personas jóvenes y } \\
\text { adultas que delinquen. } \\
\text { Son palabras que por sí solas cargan fuertes } \\
\text { significados de temor y repulsión social. }\end{array}$ \\
\hline
\end{tabular}

Fuente: Elaboración propia (2016), según monitoreo de medios de comunicación. 
En el Cuadro 2, fue posible observar las palabras o calificativos empleados por los medios de comunicación para presentar las notas periodísticas acerca de la población privada de libertad. En ellas, es posible captar en el mensaje la intencionalidad de retratar ambientes peligrosos, violentos, criminales $\mathrm{u}$ oscuros, lo que a su vez despierta sentimientos adversos en la persona que lee la noticia.

El lenguaje utilizado por los medios de comunicación, como se observa, busca representar la realidad de los centros penales a partir de la premisa de que son espacios no por todos conocidos; son espacios con amplios controles de seguridad en su ingreso, solo accesibles para quienes visitan a alguno de los suyos en prisión. De esta manera, el medio de comunicación intenta retratar realidades por medio del mensaje escrito para contextualizar al lector.

Es posible leer metáforas o comparaciones que despiertan el morbo alrededor de los temas y generan en cierta manera la reacción de condena, repudio y temor hacia un entorno que para algunas personas es completamente lejano o ajeno.
Entonces, es posible identificar que el tratamiento periodístico en la nota carcelaria dista mucho de la cobertura habitual de otras fuentes de información. El uso de calificativos o la descripción que se observa en la nota carcelaria no es la misma que se emplea en temas nacionales como salud, política, educación y cultura, entre otros.

La persona periodista sabe que dentro del colectivo goza de este privilegio: su palabra tiene credibilidad. Entonces, desde su visión y sus conocimientos acerca de qué es lo que le gusta recibir al público, se esfuerza por desarrollar ampliamente los diferentes hechos que se presentan en la sociedad; y cuando se trata de sucesos, despliega, con más razón, toda una cobertura especial que recopila, paso a paso, todos los detalles que desencadenaron un hecho.

Siguiendo esa misma línea de análisis han sido seleccionados algunos títulos para valorar los elementos empleados por la prensa escrita para captar la atención de la lectora o el lector y retratar su propio sentido de realidad en los centros penales, como se detalla en el Cuadro 3:

Cuadro 3 Análisis de los principales titulares publicados por La Nación, Diario Extra y CRHoy en el 2013.

\begin{tabular}{|c|c|c|}
\hline Titulares & Contenidos & Medio de comunicación \\
\hline $\begin{array}{l}\text { "Motines y agresiones ponen } \\
\text { cárceles color de hormiga" }\end{array}$ & $\begin{array}{l}\text { El título refiere al sombrío u } \\
\text { oscuro panorama que se vive en } \\
\text { las cárceles por motines y actos } \\
\text { violentos entre la población } \\
\text { privada de libertad. } \\
\text { De primera entrada, da señales } \\
\text { acerca de la inseguridad que } \\
\text { caracteriza a los centros penales. }\end{array}$ & Diario Extra \\
\hline $\begin{array}{l}\text { "Reos premian gatos con gallo } \\
\text { pinto" }\end{array}$ & $\begin{array}{l}\text { Con un alimento común en la } \\
\text { mesa costarricense y un animal } \\
\text { doméstico tradicional en } \\
\text { algunos hogares, el titular } \\
\text { presenta una noticia acerca del }\end{array}$ & Diario Extra \\
\hline
\end{tabular}




\begin{tabular}{|c|c|c|}
\hline & $\begin{array}{l}\text { trasiego de estupefacientes y } \\
\text { dinero dentro del penal, } \\
\text { mediante gatos. De tal manera } \\
\text { que despierta sentimientos en } \\
\text { aquellos que defienden los } \\
\text { animales y temor por las } \\
\text { situaciones de ilegalidad que se } \\
\text { presentan en dichas } \\
\text { instituciones. }\end{array}$ & \\
\hline $\begin{array}{l}\text { "Puñales viajan entre nalgas y } \\
\text { papel carbón" }\end{array}$ & $\begin{array}{l}\text { Utilizando una parte del cuerpo } \\
\text { humano para muchos } \\
\text { impensada, el titular refiere a la } \\
\text { forma en la que los privados de } \\
\text { libertad esconden sus armas } \\
\text { hechizas para defenderse de sus } \\
\text { iguales, en condiciones de } \\
\text { peligro. } \\
\text { El uso de las nalgas como parte } \\
\text { del cuerpo en un titular } \\
\text { despierta de este modo el morbo } \\
\text { o la curiosidad de quien lee ya } \\
\text { que podría parecerle imposible } \\
\text { el traslado de armas mediante } \\
\text { dicha zona del cuerpo. }\end{array}$ & Diario Extra \\
\hline $\begin{array}{l}\text { "Matan reo para no pagarle } \\
\text { deuda" }\end{array}$ & $\begin{array}{l}\text { Este titular denuncia la } \\
\text { violencia en centros penales } \\
\text { mediante dos delitos que son } \\
\text { comunes en esta población que } \\
\text { purga una condena: los } \\
\text { asesinatos y la venta o compra } \\
\text { de droga. }\end{array}$ & Diario Extra \\
\hline $\begin{array}{l}\text { "Defensoría alerta que menores } \\
\text { presos son quemados y golpeados } \\
\text { por otros reos" }\end{array}$ & $\begin{array}{l}\text { Además de alertar al (la) } \\
\text { lector(a) acerca de la } \\
\text { peligrosidad en las cárceles, la } \\
\text { violencia y la criminalidad, el } \\
\text { titular incluye un actor de peso } \\
\text { (La Defensoría de los } \\
\text { Habitantes) para dar más } \\
\text { credibilidad a los hechos } \\
\text { denunciados. }\end{array}$ & La Nación \\
\hline $\begin{array}{l}\text { "Intimidación y tortura imperan } \\
\text { entre reos en cárceles juveniles" }\end{array}$ & $\begin{array}{l}\text { El título aborda la situación de } \\
\text { una población privada de } \\
\text { libertad que también ocupa la } \\
\text { atención de las autoridades y la } \\
\text { sociedad misma: la juventud. } \\
\text { Con ese titular, el medio } \\
\text { evidencia acciones que son } \\
\text { también características en } \\
\text { centros penales con población } \\
\text { adulta. }\end{array}$ & La Nación \\
\hline $\begin{array}{l}\text { "Eugenio Polanco: 'La mayoría } \\
\text { tendrá sed de venganza social"" }\end{array}$ & $\begin{array}{l}\text { Tomando las declaraciones de } \\
\text { un reconocido psiquiatra y } \\
\text { exdirector de Adaptación } \\
\text { Social, el titular advierte acerca }\end{array}$ & La Nación \\
\hline
\end{tabular}




\begin{tabular}{|c|c|c|}
\hline & $\begin{array}{l}\text { de la peligrosidad que podrían } \\
\text { representar los privados de } \\
\text { libertad al salir de prisión, al } \\
\text { querer vengar las condiciones de } \\
\text { hacinamiento, insalubridad e } \\
\text { inadecuada readaptación a la } \\
\text { que han sido sometidos durante } \\
\text { su reclusión. }\end{array}$ & \\
\hline $\begin{array}{l}\text { "Jueces penales rechazan visitar } \\
\text { cárceles por falta de seguridad" }\end{array}$ & $\begin{array}{l}\text { Este titular hace referencia a la } \\
\text { sensación de inseguridad que } \\
\text { sienten los jueces que deben } \\
\text { asistir a los centros penales, por } \\
\text { las situaciones que se han } \\
\text { registrado en las últimas } \\
\text { semanas. Se alega que por } \\
\text { dichas situaciones, estos } \\
\text { profesionales se niegan a hacer } \\
\text { las respectivas visitas. }\end{array}$ & La Nación \\
\hline $\begin{array}{l}\text { "Reos recién salidos de prisión } \\
\text { mataron } 32 \text { personas en } 2 \text { años" } \\
\text { " } 73 \% \text { de presos elegidos para } \\
\text { dejar cárceles son asaltantes" } \\
\text { "33 convictos fueron asesinados } \\
\text { al poco tiempo de dejar la cárcel" }\end{array}$ & $\begin{array}{l}\text { Estos titulares, en diferentes } \\
\text { informaciones, hacen referencia } \\
\text { al posible destino que tendrían } \\
\text { las personas privadas de libertad } \\
\text { una vez que abandonan la } \\
\text { cárcel. Con el uso de } \\
\text { estadísticas, vislumbra un futuro } \\
\text { desalentador para quienes } \\
\text { esperan salir de prisión y tomar } \\
\text { una segunda oportunidad para } \\
\text { la vida en sociedad. }\end{array}$ & La Nación \\
\hline $\begin{array}{l}\text { "Mujer que pide indulto por } \\
\text { matar a bebé: 'Yo no estaba } \\
\text { bien"” } \\
\text { "Mujer indultada: 'En la cárcel } \\
\text { hay mucha droga"” } \\
\text { "Regalan libertad a } 3 \text { mamás } \\
\text { reclusas" } \\
\text { "Privadas de libertad del Buen } \\
\text { Pastor [hoy Vilma Curling } \\
\text { Rivera] celebrarán día de la } \\
\text { madre en medio del } \\
\text { hacinamiento" }\end{array}$ & $\begin{array}{l}\text { Las palabra madre y mujer } \\
\text { connotan una serie de } \\
\text { significados en relación con la } \\
\text { construcción social y natural de } \\
\text { la protección, el cuidado y la } \\
\text { crianza. Entonces, al incluirla } \\
\text { en el titular de inmediato } \\
\text { despierta sentimientos } \\
\text { maternales que se mezclan con } \\
\text { los sentimientos que despierta la } \\
\text { cárcel y los deseos de libertad de } \\
\text { quienes esperan la gracia del } \\
\text { indulto presidencial. }\end{array}$ & $\begin{array}{l}\text { La Nación } \\
\text { La Nación } \\
\text { Diario Extra } \\
\text { CRHoy }\end{array}$ \\
\hline $\begin{array}{l}\text { "Reclusas pagan } \$ 50 \text { mil por litro } \\
\text { de Cacique" }\end{array}$ & $\begin{array}{l}\text { Un titular que nuevamente pone } \\
\text { en evidencia la falta de control } \\
\text { en los centros penales, con el } \\
\text { ingreso de licor y la posibilidad } \\
\text { de contar con mucho dinero }\end{array}$ & Diario Extra \\
\hline
\end{tabular}


para la compra de licores y otras sustancias.

Fuente: Elaboración propia (2016), a partir de las declaraciones de las mujeres privadas de libertad.

Del Cuadro 3 puede deducirse que si bien es cierto los medios presentes utilizan sus propias estrategias para relatar la realidad observada y captar la atención del público, el Diario Extra es el medio de comunicación que emplea un vocabulario más popular, más sencillo e incluso más carente de elegancia. Sus expresiones son más apegadas a lo callejero, en el buen sentido de la palabra, atendiendo a esa comodidad y simpleza de lenguaje que demanda un sector de la población.

En su estilo, el Diario Extra usa palabras soeces o chocantes para la sensibilidad de las personas, contrario a lo que sucede con el periódico La Nación, que utiliza un vocabulario más elaborado, respaldado en estadísticas $\mathrm{o}$ declaraciones oficiales en sus titulares. Recordemos que ambos diarios responden a públicos o clases sociales diametralmente opuestos en poder adquisitivo y educación, entre otros factores diferenciadores.

Por ejemplo, en sus informaciones es recurrente establecer relación entre la población privada de libertad y animales para delinquir dentro de los centros penales, lo que despierta el morbo de las personas lectoras y retrata una realidad malsana y aberrante.

Incluso en las denuncias que realiza el medio sobre conductas no apropiadas dentro de un centro penal, utiliza en sus titulares la reproducción de la violencia, del maltrato y de las difíciles relaciones existentes entre la población penitenciaria.
Por su parte, el periódico La Nación emplea un vocabulario más formal, no obstante, no se niega a reproducir las conductas violentas que se originan en centros penales y refuerza estos mensajes con la mención de fuentes oficiales de alta confianza y credibilidad en la opinión pública, entre ellos la Defensoría de los Habitantes, jueces y exdirectores penitenciarios.

En otras informaciones, al consignar citas porcentuales de casos registrados con personas que cumplen sus condenas, el diario orienta sus titulares al posible futuro que tendrán estas personas en su intento por reinsertarse en la sociedad, dejando ver que toda intención es fallida.

\section{Las privadas de libertad comentan la noticia}

\section{Mi familia sintió vergüenza de ver que mi detención, salió en todos los canales. Luisa - nombre ficticio-}

(comunicación personal, 3 de junio del 2015)

La exposición a la que son objeto las privadas de libertad durante su detención y todo el proceso judicial que siguen por su caso les llena de pena. Ellas son conscientes de que al acaparar la atención de la opinión pública por medio de la prensa no solo afecta su imagen: también, pone al desnudo la integridad de sus familias. Este es quizás uno de los asuntos que más les atormenta dentro de sus procesos: el dolor y la vergüenza de los suyos.

El pensar que han desilusionado a sus seres queridos se materializa en un 
sentimiento de culpa que las acompaña por siempre. Así lo afirman ellas desde el primer momento en que acceden a conceder una entrevista para los efectos de la presente investigación. Esos sentimientos afloran en su forma de expresarse, de comportarse, en lo que percibimos como comunicación no verbal o corporal. De pronto, sus manos se vuelven inquietas, sus cuerpos comienzan a moverse con preocupación aún sentadas sobre sillas que ofrecen cierta comodidad y sus rostros lo ratifican todo: la tristeza humedece sus ojos, sus facciones se caen con pesar y su voz titubea.

Al recordar esta historia y contarla, Luisa no puede controlar el temblor de su voz y las lágrimas que llevan sus ojos. De pronto se detiene y dice acordarse y sentir el dolor en su corazón tal cual lo experimentó ese día. Refiere haber sentido el deseo inmenso de querer evitar que las cámaras fotográficas y de video, y aquellas personas de la prensa reprodujeran su vida privada $\sin \mathrm{su}$ consentimiento y sin respeto a su familia ni a su vida propia.

"Fue muy trágico porque todos los medios estaban ahí grabando (la detención de Luisa) y porque realmente una de las oficiales me ayudó porque dijo: 'No; tápenle la cara' cuando pasaba todo. Entonces, ella misma se quitó una chaqueta que ella llevaba y me la puso en la cara para que no se me viera. Cuando me llevaron a mi casa también iban los medios atrás y otros estaban allá afuera donde está el operativo y yo les dije 'que se quiten ellos si no yo no entro' y a propósito me llevaron. La única fuerza era la oficial y yo tapándome para que no se me viera la cara; pero mi mamá sí me dijo: 'Cálmese porque al menos no se le vio la cara; solo en el (canal) 42 que salió toda la carita". (Luisa -nombre ficticio-, comunicación personal, 3 de junio del 2015).
Al relatar sus historias, ellas reviven el dolor. Haber perdido su libertad y permanecer distanciadas de los suyos les afecta notablemente. No obstante, también reconocen que su permanencia en prisión obedece a su más grande error. Admiten con resignación que deben pagar con su libertad los delitos cometidos; pero manifiestan la confianza en que pronto retomarán sus vidas, al lado de sus familias.

En ellas se mantiene la esperanza de un futuro mejor. Son conscientes de que el tiempo pasa y con ilusión ven sus vidas con optimismo.

En esa sentencia judicial que les fue impuesta reconocen su culpa; saben que una equivocación en su vida tuvo consecuencias graves para su vida personal, familiar y social. Sin embargo, reprueban la sentencia social que afirman les impone la prensa nacional; una sentencia que, aunque permanece unos días reflejada en un papel periódico dentro de la opinión pública, les da de por vida una etiqueta que para ellas trasciende el tiempo, la prisión y el recuerdo.

Ellas consideran al o la periodista como un segundo juez, que dicta una nueva sentencia a sus vidas; una sentencia que tiene más impacto, pues perdurará más allá de los años que deban estar en prisión. $\mathrm{Su}$ sentencia judicial termina al salir del penal, queda en su expediente $u$ hoja de delincuencia, pero privada y solo conocida por aquellos que busquen ese tipo de información. Mas la sentencia que emite la prensa es perenne, consideran. Es una sentencia pública, que atrapa a sus seres queridos y que regresa tan solo con sacar nuevamente un recorte de periódico o en el relato que los otros hagan sobre ellas por el impacto de las coberturas periodísticas desarrolladas de sus casos.

"Salí en La Nación, Al Día, la Extra, La Teja, el 6, el 7, el 11 y el 42 [...]. Hay cosas en las que sí dicen la verdad y hay otras 
que de verdad exageran". (Sylvia -nombre ficticio-, comunicación personal, 3 de junio del 2015).

Señalan que ese periódico que expone sus rostros, sus historias, sus familias y su entorno, el más privado, dura unos días en el recuerdo de la gente; pero no en el de sus familias y el de ellas mismas. Incluso, ese periódico es recurrente cuando dentro del penal registran momentos crudos en la convivencia con otras mujeres privadas de libertad. Ese periódico pasa a ser un arma moral de impacto, cuando en medio de la crisis sale a relucir para recordar la "peligrosidad" o la magnitud del delito que pudieron cometer en el pasado.

Ese periódico se convierte, entonces, en un recordatorio constante que para sí mismas remueve sentimientos y para las demás inspira el deseo de recordar lo "peligrosas" o "malas" que pudieron ser un día en la sociedad que han abandonado.

Según las conversaciones sostenidas con ellas y el fondo de sus declaraciones, se extrajeron frases acerca del trabajo de la prensa escrita durante y posterior a su detención, así como en el momento de su ingreso a prisión, en aras de determinar a cuáles sentimientos se asociaban sus palabras cuando hablaban de sus experiencias con los medios de comunicación.

De las conversaciones, se extrajo la información que se detalla en el Cuadro 4:

Cuadro 4 Emociones expresadas por las mujeres privadas de libertad en sus declaraciones sobre el trabajo de la prensa en la cobertura de sus propios casos.

\begin{tabular}{|c|c|c|c|c|c|}
\hline $\begin{array}{l}\text { Consecuencias } \\
\text { de la cobertura } \\
\text { periodística }\end{array}$ & $\begin{array}{l}\text { Palabras } \\
\text { clave }\end{array}$ & $\begin{array}{l}\text { Exposición en } \\
\text { los medios }\end{array}$ & $\begin{array}{l}\text { Palabras } \\
\text { clave }\end{array}$ & $\begin{array}{l}\text { Críticas al } \\
\text { accionar de la } \\
\text { prensa escrita }\end{array}$ & $\begin{array}{l}\text { Palabras } \\
\text { clave }\end{array}$ \\
\hline $\begin{array}{l}\text { "Mi familia sintió } \\
\text { vergüenza" }\end{array}$ & Vergüenza & $\begin{array}{l}\text { "Salió en } \\
\text { todos los } \\
\text { canales" }\end{array}$ & Enojo & $\begin{array}{l}\text { "Él para } \\
\text { lucirse, me } \\
\text { jaló" }\end{array}$ & Enojo \\
\hline $\begin{array}{l}\text { "Fue muy } \\
\text { trágico" }\end{array}$ & Vergüenza & $\begin{array}{l}\text { "Estaban } \\
\text { todos los } \\
\text { medios" }\end{array}$ & Enojo & $\begin{array}{l}\text { "Ellos mismos } \\
\text { me juzgaban } \\
\text { por lo que } \\
\text { habían dicho } \\
\text { los medios sin } \\
\text { saber cómo } \\
\text { habían pasado } \\
\text { las cosas } \\
\text { realmente" }\end{array}$ & Frustración \\
\hline $\begin{array}{l}\text { "Al menos no se } \\
\text { le vio la cara" }\end{array}$ & Vergüenza & $\begin{array}{l}\text { "Todos los } \\
\text { medios } \\
\text { estaban ahí } \\
\text { grabando" }\end{array}$ & Enojo & $\begin{array}{l}\text { "Hay cosas en } \\
\text { las que sí } \\
\text { dicen la } \\
\text { verdad y hay } \\
\text { otras que de } \\
\text { verdad } \\
\text { exageran" }\end{array}$ & Frustración \\
\hline $\begin{array}{l}\text { "Solo en el } \\
\text { (canal) } 42 \text { que } \\
\text { salió toda la } \\
\text { carita" }\end{array}$ & Vergüenza & $\begin{array}{l}\text { "Cuando me } \\
\text { llevaron a mi } \\
\text { casa también } \\
\text { iban los } \\
\text { medios atrás" }\end{array}$ & Enojo & $\begin{array}{l}\text { "Mi familia } \\
\text { dijo que eran } \\
\text { mentirosos" }\end{array}$ & Enojo \\
\hline
\end{tabular}




\begin{tabular}{|c|c|c|c|c|c|}
\hline $\begin{array}{l}\text { "Ellos se } \\
\text { preguntaban de } \\
\text { cómo yo había } \\
\text { aterrorizado a la } \\
\text { comunidad" }\end{array}$ & Frustración & $\begin{array}{l}\text { "Otros estaban } \\
\text { allá afuera } \\
\text { donde está el } \\
\text { operativo" }\end{array}$ & Enojo & $\begin{array}{l}\text { "Cómo fueron } \\
\text { a decir tal } \\
\text { barbaridad } \\
\text { mía" }\end{array}$ & Frustración \\
\hline $\begin{array}{l}\text { "Un caso muy } \\
\text { explotado" }\end{array}$ & Vergüenza & $\begin{array}{l}\text { "Mi familia } \\
\text { me dijo que - } \\
\text { salí- en } L a \\
\text { Nación, Al Día, } \\
\text { la Extra y en la } \\
\text { 'tele' }\end{array}$ & Vergüenza & $\begin{array}{l}\text { "Hubieran } \\
\text { esperado e } \\
\text { investigado } \\
\text { bien todo" }\end{array}$ & Frustración \\
\hline $\begin{array}{l}\text { "Cuando ya } \\
\text { ingresé aquí, tuve } \\
\text { que hacerlo con } \\
\text { muy poco ruido } \\
\text { por la aceptación } \\
\text { de la población" }\end{array}$ & Dolor & $\begin{array}{l}\text { "Yo no sé } \\
\text { cuánto tiempo } \\
\text { estuve ahí en } \\
\text { la tele" }\end{array}$ & Vergüenza & $\begin{array}{l}\text { "A la prensa } \\
\text { no le interesa } \\
\text { lo que pasa" }\end{array}$ & Enojo \\
\hline \multirow[t]{5}{*}{$\begin{array}{l}\text { "Yo estuve año y } \\
\text { cuatro meses } \\
\text { encerrada en } \\
\text { protección para } \\
\text { evitar problemas" }\end{array}$} & Dolor & $\begin{array}{l}\text { "No pude } \\
\text { verlo... Ya no } \\
\text { quería verlo" }\end{array}$ & Enojo & $\begin{array}{l}\text { "Mientras } \\
\text { más exageran } \\
\text { más exitoso } \\
\text { va a ser" }\end{array}$ & Enojo \\
\hline & & $\begin{array}{l}\text { "Salí desde } \\
\text { que } \\
\text { empezaron -la } \\
\text { edición-, que } \\
\text { cómo iban a } \\
\text { decir algo tan } \\
\text { delicado" }\end{array}$ & Vergüenza & $\begin{array}{l}\text { "No, ya no, } \\
\text { con la prensa } \\
\text { a mí ya no" }\end{array}$ & Enojo \\
\hline & & $\begin{array}{l}\text { "Sí salí por las } \\
\text { noticias, por } \\
\text { todo lado, } \\
\text { hasta en el } \\
\text { periódico vi un } \\
\text { encabezado } \\
\text { que decía } \\
\text { 'Padres matan } \\
\text { a hija de un } \\
\text { mes' }\end{array}$ & Dolor & $\begin{array}{l}\text { "Realmente } \\
\text { las cosas no } \\
\text { pasan como } \\
\text { las dicen los } \\
\text { medios" }\end{array}$ & Enojo \\
\hline & & $\begin{array}{l}\text { "Salí en } L a \\
\text { Nación, Al Día, } \\
\text { la Extra, } L a \\
\text { Teja, el 6, el 7, } \\
\text { el } 11 \text { y el 42" }\end{array}$ & Vergüenza & $\begin{array}{l}\text { "Ellos } \\
\text { exageran } \\
\text { demasiado" }\end{array}$ & Enojo \\
\hline & & & & $\begin{array}{l}\text { "A ver si } \\
\text { quitan algún } \\
\text { día un poco } \\
\text { de lo que } \\
\text { dicen" }\end{array}$ & Frustración \\
\hline
\end{tabular}

Fuente: Elaboración propia (2016), a partir de las declaraciones de las mujeres privadas de libertad. 
Desde la subjetividad que puede acompañar la posición de las mujeres privadas de libertad que han sido noticia en los medios de comunicación, es posible identificar un descontento rotundo con los(as) periodistas, en el cumplimiento de su labor. El abordaje que los(as) periodistas hacen del acontecimiento las llena de insatisfacción por considerar que sus vidas privadas son expuestas a la opinión pública sin haber retomado $\mathrm{o}$ indagado por completo acerca de todos los detalles de sus casos. El descontento hacia la cobertura de su caso se extiende por solidaridad o empatía hacia sus similares, en una complicidad o comprensión que llega por estar atravesando situaciones difíciles en la privación de su libertad.

Es posible, incluso, verlas abordar el ejercicio periodístico con mucha criticidad, desmenuzando cada uno de los pasos recorridos por el o la periodista en la cobertura de la noticia. Ellas alegan desconocer los métodos y las normas que componen el tratamiento de la noticia; pero analizan la actuación de la prensa escrita desde los resultados mismos de esa cobertura sobre su situación; es decir, la noticia publicada el número de veces decidido por el medio de comunicación.

Por ejemplo, reprochan rotundamente el hecho de que los cuerpos policiales den aviso de los operativos o las detenciones y que la prensa escrita sea un actor fundamental en los procedimientos policiales con cámaras y profesionales del periodismo destacados en todos los lugares involucrados en las acciones policiales. Una de ellas indicaba que fue detenida en la vía pública, a escasos metros de su casa. Su detención fue captada por las cámaras y el allanamiento en su casa de habitación también fue captado por el lente periodístico. Se preguntaban, entonces, cómo logra la prensa enterarse de las ubicaciones de todos los operativos policiales. Si bien son conscientes de que la prensa debe cumplir con su trabajo, no son partidarias de esa idea de ver a los medios de comunicación masiva cubriendo la nota del suceso como si fueran parte de los equipos policiales encargados de los operativos.

Este ha sido uno de los temas presentes en la opinión pública durante años, pues se dice que la fuga de información policial a los medios de comunicación podría entorpecer la labor policial en la ejecución de allanamientos, detenciones y traslados de privados de libertad, entre otras acciones. La noticiabilidad de esos hechos rojos ha provocado que la prensa escrita se cuele en los operativos mediante contactos de información que dan detalle de la agenda policial. Tal vez sea esta una forma para los cuerpos policiales de ver reconocida su labor, si esta es exhibida en la opinión pública como muestra de la efectividad de su trabajo.

Ellas alegaron haber preferido que los medios de comunicación indagaran aún más de su situación, con ellas o con sus familiares; pero sienten que hizo falta anotar en las informaciones su versión de los hechos.

Al analizar el centro penal como un círculo social, como un espacio donde conviven bajo las mismas condiciones, se identifican también consecuencias importantes por la generación de estereotipos propios de las informaciones. La reproducción de la noticia y el limitado, aunque certero, acceso que tienen las poblaciones privadas de libertad a los medios de comunicación social, crean en menor escala las mismas situaciones que a nivel general se dan en la sociedad con la difusión de los acontecimientos por parte de la prensa escrita.

Las condiciones que ocurren dentro de las instituciones carcelarias pueden ser incluso más graves que lo que ocurre a una escala mayor, a nivel social. Cuentan las 
privadas de libertad que la llegada al penal puede ser una completa pesadilla si dentro se genera un ambiente de reproche por el delito cometido: o sea, si dentro de prisión llegan a tener conocimiento de un caso con características que ellas consideren deplorables, esperan la llegada de esa persona para ejercer contra ella el castigo a sus actos. Estas manifestaciones de violencia $\mathrm{y}$ agresión se presentan especialmente en casos en los cuales estén involucrados(as) menores de edad o hijos(a), pues muchas de ellas llegan a desarrollar tantos sentimientos de culpa por haber dejado a sus hijos(as) con otras personas, que no aceptan que una mujer atente o violente a un(a) niño(a).

El Gráfico 1 detalla los sentimientos que les generan estas publicaciones a las mujeres privadas de libertad:

Gráfico 1 Sentimientos de las privadas de libertad frente a la cobertura periodística de sus propios casos.

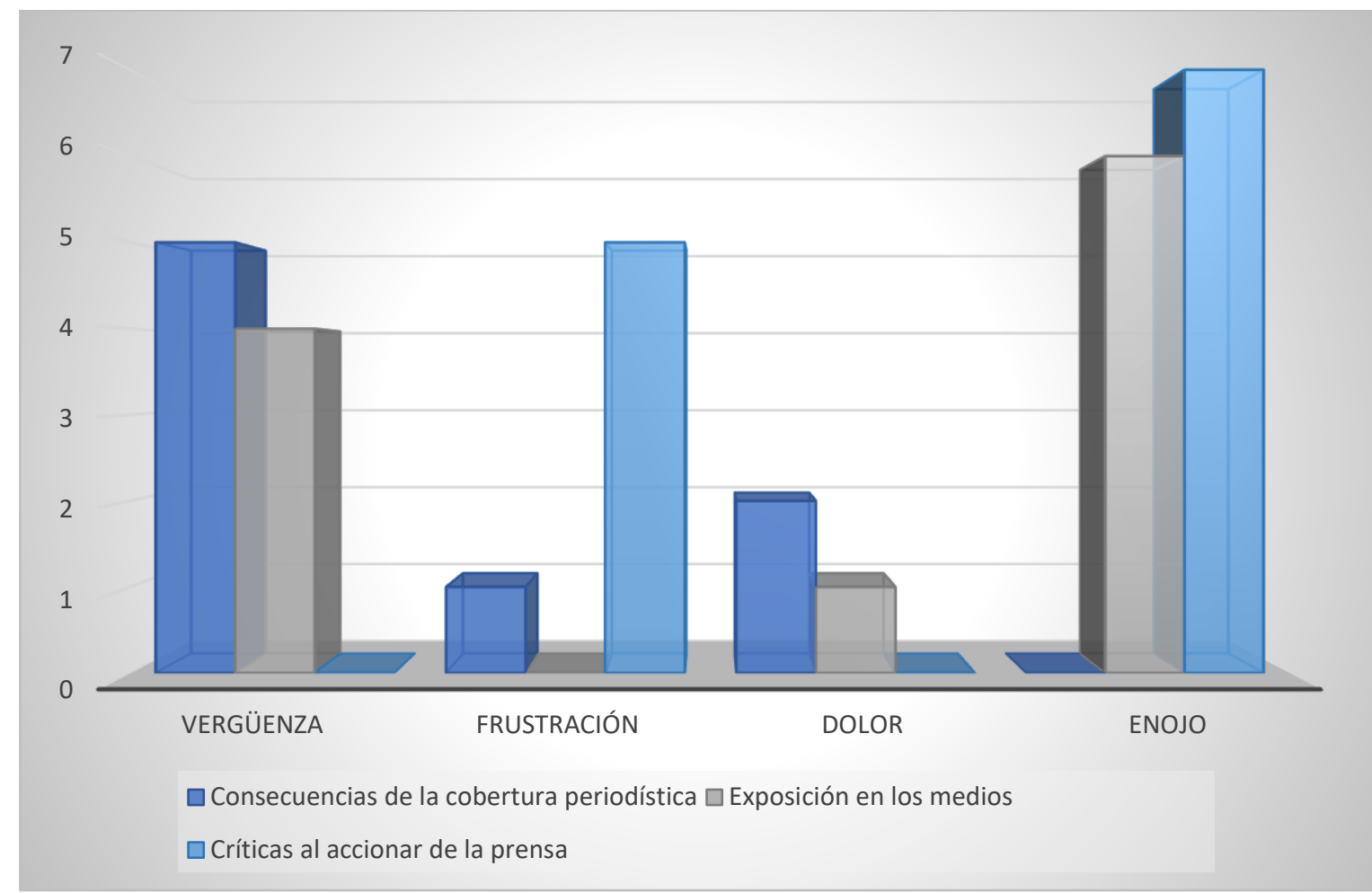

Fuente: Elaboración propia (2016), a partir de entrevistas personales a las mujeres privadas de libertad.

Para ellas, la sobreexposición de sus casos de manera reiterada, y en condiciones que según ellas no estuvieron apegadas a la verdad, genera consecuencias negativas en sus vidas: a nivel personal, familiar, social y grupal; se entiende este último como las relaciones interpersonales entre iguales, una vez que son ubicadas en los módulos respectivos, en prisión.

A nivel personal, expresan sentir gran consternación por la forma en la que fueron retratadas ante la sociedad. En este particular entran en juego los calificativos, sinónimos y otro tipo de características que son empleados por la prensa escrita para presentar la noticia. Anteriormente, analizamos algunas de las frases $o$ palabras que son usadas con frecuencia en los medios de comunicación para presentar la nota, para ofrecerle a quien lee una información que le haga transportarse a la situación misma, como herramientas o técnicas periodísticas empleadas para crear más impacto en la opinión pública.

Este uso de calificativos -afirmaban- las hizo parecer personas malas. La maldad 
para ellas está lejos de sus casos, pues dentro de la subjetividad propia del ser humano consideran que sus delitos fueron cometidos por diferentes circunstancias no relacionadas con la maldad, sino más bien producto de errores o equivocaciones que se pagaron caro en sus vidas, con su propia libertad.

En todos los casos, afirmaron haber sido expuestas ante la opinión pública como personas nada parecidas a ellas mismas, en su desenvolvimiento habitual con los demás seres humanos. El detalle de los acontecimientos, que incluso consideran exagerado, provocó reacciones de asombro, de dolor, de angustia y de desilusión en sus seres queridos. Tal situación generó en ellas más tensión, desasosiego y frustración al sentir que desilusionaron a los suyos. En el caso de las mujeres con hijos(as), estos sentimientos se acrecentaron pues asoman en ellas los sentimientos propios de la maternidad que son asumidos personal y socialmente por las mujeres desde edades muy tempranas, como ese rol que ha sido dado de manera ancestral.

Es entonces como cargan además de su condena penal, una pena natural por el peso que conlleva haberles fallado a sus hijos(as) y tener que separarse de ellos(as), de todas sus etapas de crecimiento por un error que les privó de su libertad. En su discurso, es posible identificar arrepentimiento, resignación y tristeza cuando retoman el pasado y recuerdan sus delitos. Saben que no hay ahora marcha atrás en sus vidas y deben cumplir una condena impuesta en tribunales; empero, no dejan de sentir esos deseos de devolver el tiempo para haber evitado sus delitos y, además, para haber vivido de manera diferente, alejadas de las situaciones que las llevaron a delinquir.

En sus entornos familiares, lograron encontrar el apoyo para enfrentar sus casos, pero el manejo de las relaciones con sus seres queridos fue difícil cuando la prensa escrita se convirtió en emisor de sus realidades, una verdad que pudo haber sido contada por ellas: pero la prensa les ganó la batalla. Además, en esa difusión de sus noticias, consideran que también fue violentada la intimidad de sus familias, puesto que fueron expuestos detalles como sus viviendas, sus condiciones familiares, su información personal (apellidos, edades, oficios y parentescos, entre otros datos), y sus relaciones entre vecinos o miembros de la misma comunidad.

En el plano social, esta revelación de datos provocó la generación y reproducción de estereotipos que pronto corrieron para identificarlas en sus propios entornos cercanos; adicionalmente, en algunos casos, a nivel nacional. Es así como ellas y sus familias debieron enfrentar una condena o una etiqueta sociales al ser vinculados todos con el caso que difundió la prensa escrita. Dentro del plano emocional, no solo fueron afectadas ellas mismas; lo fueron también sus familias, sus amistades) y personas allegadas durante todo el proceso de exposición y luego de este.

Como si se tratara de dos capítulos, estas condiciones se vuelven a revivir por segunda vez cuando son llevadas a juicio, cuando se ratifica su sentencia y en algunos casos, cuando son trasladadas al centro penal asignado, lo que las lleva a una revictimización, a una doble condena social, a la ratificación social de todos los calificativos empleados anteriormente cuando aún las amparaba el principio de inocencia, antes del juicio.

El Cuadro 5 resume los sentimientos encontrados en las mujeres privadas de libertad y es la muestra más representativa que viene a confirmar lo indicado en el gráfico 7 , en el cual el enojo es el que más les ha afectado, con 13 repeticiones de un total de 31: 
Gráfico 2 Repeticiones en los sentimientos expresados por las privadas de libertad al referirse a la cobertura periodística de sus propios casos.

\begin{tabular}{|l|l|}
\hline Sentimiento & Cantidad de repeticiones \\
\hline Dolor & 3 \\
\hline Frustración & 6 \\
\hline Vergüenza & 9 \\
\hline Enojo & 13 \\
\hline Total & 31 \\
\hline
\end{tabular}

Fuente: Elaboración propia (2016) a partir de las entrevistas personales a mujeres privadas de libertad.

En esa búsqueda justificada de elementos que fortalezcan la noticia, el o la periodista sucumbe ante el acontecimiento para explotar todos y cada uno de los detalles ahí disponibles, a fin de asegurarse sus lectores, telespectadores o radioescuchas, según sea el caso, $\mathrm{y}$, además, para competir fuertemente contra sus colegas de otros medios, procurando dar enfoques diferentes, información diversa y perspectivas distintas; en fin, una nota diferente, pero que genera sentimientos adversos en la población protagonista de la información.

Ellas, las reclusas entrevistadas, difieren de varios elementos empleados por los periodistas en la presentación de la noticia, desde la forma de recopilar la información hasta la publicación $\mathrm{o}$ divulgación del hecho, en la cobertura periodística. Frente a esto, afirman haber sentido emociones como dolor, frustración, vergüenza y enojo.

El Gráfico 2 nos muestra cómo un sentimiento tan fuerte como el dolor, no es tan representativo en el impacto que genera en ellas la cobertura periodística de sus casos, como sí lo es el enojo hacia esta situación. En este caso, el enojo afecta más profundamente a las privadas de libertad, pues se unen a ellas sentimientos ligados a la familia $y$ su exposición ante la comunidad y el país:

Gráfico 3 Cantidad de repetición de sentimientos de las mujeres privadas de libertad al referirse a la cobertura periodística de sus propios casos.

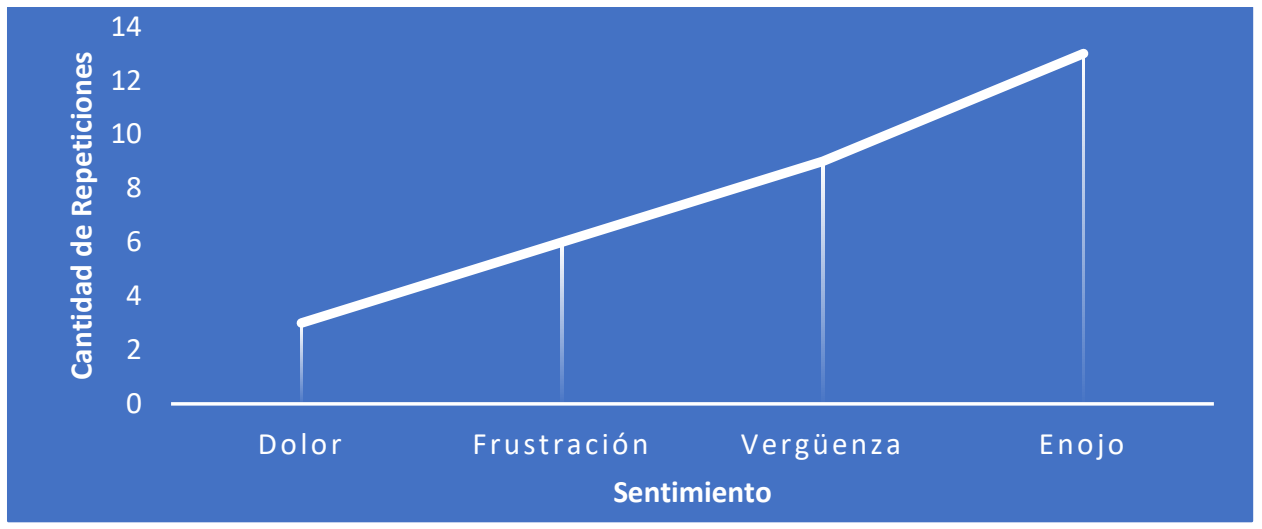

Fuente: Elaboración propia (2016) a partir de entrevistas personales a mujeres privadas de libertad.

El tema carcelario está presente en la prensa escrita nacional con marcada frecuencia. Las secciones de sucesos exponen constantemente notas periodísticas que evocan la palabra cárcel de forma directa o indirecta, ya que es el "castigo" o desenlace del delito cometido dentro del orden social. Diversas 
aproximaciones académicas han dado cuenta del interés que existe en el público por la información de sucesos. De hecho, no es casualidad que las noticias de esta naturaleza aparezcan casi siempre en las portadas de los periódicos o que los noticieros televisivos y radiofónicos coloquen estas notas al inicio de sus ediciones y hasta por 10 minutos. En otros casos, se presentan transmisiones $\mathrm{o}$ informaciones en vivo que interrumpen la edición normal del bloque de noticias o la programación habitual de los medios de comunicación para dar cuenta de un suceso de última hora.

Al colocar a esta población como protagonista de la investigación, se asumen limitaciones en cuanto al acceso a las personas sujetas de estudio, por estar inmersas en un ambiente con seguridad extrema, como el centro penitenciario. Por las características de la población, también se dificultan los procesos de consulta de trabajos anteriores porque son escasos en las universidades estatales y privadas.

Es primordial recalcar que el abordaje de este tema, la publicación de sus propias situaciones personales, es posible que atraiga relatos con alguna subjetividad que, probablemente, volcaría la balanza hacia lo "injusto" que puede parecer el ejercicio de la prensa escrita en la cobertura de la nota de sucesos.

Asimismo, la autorización para trabajar únicamente con cuatro privadas de libertad, debido a las directrices emitidas por el Ministerio de Justicia y Paz de evitar la proliferación de trabajos de investigación en el penal, limita en cierta medida el tamaño de la población de estudio y cierra las posibilidades de aplicar otras estrategias metodológicas de las cuales se deriven más datos para el análisis.

Las condiciones que ocurren dentro de las instituciones carcelarias pueden ser incluso más graves que lo que ocurre a una escala mayor, a nivel social. Cuentan las privadas de libertad que la llegada al penal puede ser una completa pesadilla si dentro se genera un ambiente de reproche por el delito cometido; dicho de otro modo, si dentro de prisión llegan a tener conocimiento de un caso con características que ellas consideren deplorables, esperan la llegada de esa persona para ejercer contra ella el castigo a sus actos. Estas manifestaciones de violencia y agresión se presentan en especial en casos en los cuales estén involucrados menores de edad, hijos o hijas, pues muchas de ellas llegan a desarrollar tantos sentimientos de culpa por haber dejado a su descendencia con otras personas, que no aceptan que una mujer atente o violente a un niño o niña. Este fue el caso de una de las entrevistadas, quien descuenta una condena por el homicidio de su hija de meses. Afirma que tanto ella como su esposo trataron de revivir a su hija que quedó inconsciente, sin respuesta alguna; pero al ser llevada por los cuerpos de socorro a un centro médico se determinó que la niña había muerto por una fuerte sacudida y la pareja fue encontrada culpable por el fallecimiento de la menor.

En su relato, ella cuenta que al ingresar al centro penal tuvo que ser custodiada por oficiales, pues las demás privadas de libertad querían vapulearla. Ella, incluso, fue separada del resto de la población por unos días para procurar que se calmaran los ánimos de las mujeres privadas de libertad que querían cobrarle la muerte de su hija. Para ella, la falta de espacio para explicar lo ocurrido con su hija, la desatención de la prensa escrita hacia su propia versión $\mathrm{y}$, además, el haber presentado su incidente con morbo causó en las demás mujeres sentimientos violentos.

Situaciones como las anteriores, las hacen reflexionar acerca del cuidado que afirman deberían tener los periodistas al 
publicar las informaciones. Igualmente,, las hace pensar en las condiciones que enfrentarán una vez que salgan de prisión y deban regresar a la sociedad para continuar con sus vidas habituales.

Para algunas de ellas probablemente sus casos no permanezcan ya en el recuerdo de las personas y encuentran consuelo en ello; mas no dejan de pensar en la exposición que tuvieron y en los daños morales, emocionales y psicológicos que enfrentaron ellas mismas, sus familiares y seres queridos.

Esta investigación encuentra que es indispensable que la prensa nacional replantee el ejercicio de su función en la cobertura de sucesos en aras de no consignar en sus informaciones juicios de valor que puedan facetar a las mujeres con condena, en su ingreso al penal y en su proceso de reinserción social.

Tomas (2015) defiende, no obstante, la preparación interdisciplinaria que acompaña al y a la periodista de la llamada "nota roja". Asegura que para la elaboración de las notas, las personas profesionales deben conocer bien la materia legal para escribir acorde con lo tipificado por las leyes y más bien no convertirse en blanco o "chota" de los profesionales por escribir, narrar $\mathrm{o}$ comentar hechos que no dominan.

A su juicio, tal preparación no es similar para alguien que cubre política, deportes, laborales o sociales.

\section{Conclusiones}

Las mujeres privadas de libertad experimentan consecuencias que afectan su desenvolvimiento social en el centro penal a raíz de la cobertura mediática. Ellas sienten atropellada su integridad en la cobertura del suceso. Mucho de estas acciones por parte de profesionales obedece al periodismo funcionalista instaurado en nuestro país para cumplir únicamente con los estándares comerciales de un negocio pujante.

Al recordar sus casos y la exposición que tuvieron en la prensa escrita, rechazan la metodología de trabajo desarrollada por el y la profesional en periodismo a la hora de dar cobertura informativa a sus delitos, su detención e ingreso al penal. Esta situación evidencia la necesidad de intervenir de manera constructiva el trabajo periodístico en la redacción $\mathrm{y}$ elaboración de contenidos informativos, en aras de instaurar un ejercicio más humano, más consciente, y más apegado a su función social y mediadora del desarrollo integral del ser humano.

Independiente de los motivos que enumeran para defender su derecho a ser abordadas, a quien ejerce el periodismo de nota roja frecuentemente se le olvida este derecho innegable de las personas detenidas de dar la versión de los hechos. Muchas veces se le confiere poca importancia por la rapidez de los actos, por el cerco policial, por la condena pública de considerar que las pesquisas policiales que llevaron a los procedimientos de detención $\mathrm{y}$ allanamiento son certeras, o bien, porque la misma persona detenida se niega a declarar a los medios de comunicación. Con estas mujeres, el caso era otro. Ellas alegaron haber preferido que los medios de comunicación indagaran aún más de su situación, con ellas o con sus familiares; pero sienten que hizo falta anotar su versión de los hechos en las informaciones.

De la forma en la que fueron presentadas sus noticias, ellas tenían mucho que decir. El espacio facilitado para conversar con ellas se prestó para que una por una expusiera su caso; no obstante, la empatía que han generado entre ellas al compartir un mismo entorno las hizo apoyarse cuando les correspondió hablar acerca de las implicaciones que la publicación de sus 
casos tuvo en sus vidas personales, en su círculo familiar y social, y en la convivencia dentro del penal.

Para ellas, la sobreexposición de sus casos de manera reiterada y en condiciones que según ellas no estuvieron apegadas a la verdad, genera en sus vidas consecuencias negativas en sus vidas: a nivel personal, familiar, social y grupal; se entiende este último como las relaciones interpersonales entre iguales, una vez que son ubicadas en los módulos respectivos, en prisión.

A nivel personal, expresan sentir gran consternación por la forma en la que fueron retratadas ante la sociedad. En este particular entran en juego los calificativos, sinónimos y otro tipo de características que son empleados por la prensa escrita para presentar la noticia. Anteriormente, analizamos algunas de las frases $o$ palabras que son usadas con frecuencia en los medios de comunicación para presentar la nota, para ofrecerle al lector una información que le haga transportarse a la situación misma, como herramientas o técnicas periodísticas empleadas para crear más impacto en la opinión pública.

Este uso de calificativos -afirmaban- las hizo parecer personas malas. La maldad para ellas está lejos de sus casos, pues dentro de la subjetividad propia del ser humano consideran que sus delitos fueron cometidos por diferentes circunstancias no relacionadas con la maldad, sino más bien producto de errores o equivocaciones que se pagaron caro en sus vidas, con su propia libertad.

En todos los casos, afirmaron haber sido expuestas ante la opinión pública como personas nada parecidas a ellas mismas, en su desenvolvimiento habitual con los demás seres humanos. El detalle de los acontecimientos, que incluso consideran exagerado, provocó reacciones de asombro, de dolor, de angustia y de desilusión en sus seres queridos. Esta situación generó en ellas más tensión, desasosiego y frustración al sentir que desilusionaron a los suyos. En el caso de las mujeres con hijos o hijas, tales sentimientos se acrecentaron, pues asoman en ellas los sentimientos propios de la maternidad que son asumidos personal y socialmente por las mujeres desde edades muy tempranas, como ese rol que ha sido dado de manera ancestral.

Es, entonces, como cargan además de su condena penal, una pena natural por el peso que conlleva haberles fallado a sus hijos e hijas y tener que separarse de ellos, de todas sus etapas de crecimiento por un error que les privó de su libertad. En su discurso es posible identificar arrepentimiento, resignación y tristeza cuando retoman el pasado y recuerdan sus delitos. Saben que no hay ahora marcha atrás en sus vidas y deben cumplir una condena impuesta en tribunales; aunque no dejan de sentir esos deseos de devolver el tiempo para haber evitado sus delitos y, además, para haber vivido de manera diferente, alejadas de las situaciones que las llevaron a delinquir.

En sus entornos familiares lograron encontrar el apoyo para enfrentar sus casos; pero el abordaje de las relaciones con sus seres queridos fue difícil cuando la prensa escrita se convirtió en emisor de sus realidades, una verdad que pudo haber sido contada por ellas; no obstante, la prensa les ganó la batalla. En adición, en esa difusión de sus noticias, consideran que también fue violentada la intimidad de sus familias, puesto que fueron expuestos detalles como sus viviendas, sus condiciones familiares, su información personal (apellidos, edades, oficios y parentescos, entre otros datos), y sus relaciones entre vecinos o miembros de la misma comunidad.

En el plano social, esta revelación de datos provocó la generación y reproducción de estereotipos que pronto corrieron para identificarlas en sus propios entornos cercanos, además en algunos casos, a nivel 
nacional. Es así como ellas y sus familias debieron enfrentar una condena social o una etiqueta sociales al ser vinculados con el caso que difundió la prensa escrita. Dentro del plano emocional, no solo fueron afectadas ellas mismas; lo fueron también sus familias, sus amigos y allegados durante todo el proceso de exposición y luego de este.

Como si se tratara de dos capítulos, estas condiciones se vuelven a revivir por segunda vez cuando son llevadas a juicio, cuando se ratifica su sentencia y en algunos casos, cuando son trasladadas al centro penal asignado, lo que las lleva a una revictimización, a una doble condena social, a la ratificación social de todos los calificativos empleados anteriormente cuando aún las amparaba el principio de inocencia, antes del juicio.

Al analizar el centro penal como un círculo social, como un espacio donde conviven bajo las mismas condiciones, se identifican también consecuencias importantes por la generación de estereotipos propios de las informaciones. La reproducción de la noticia y el limitado pero certero acceso que tienen las poblaciones privadas de libertad a los medios de comunicación social crean en menor escala las mismas situaciones que a nivel general se dan en la sociedad con la difusión de los acontecimientos por parte de la prensa escrita.

\section{Recomendaciones}

Al finalizar la investigación, se recomienda la creación en Costa Rica de la figura del Ombudsman del Lector, creada en el diario japonés Asahi Shimbun en 1922, del cual no se tienen registros informativos que detallen sus tareas ni que evidencien que haya sido replicado en otros países. De esta forma, podrían fiscalizarse $\mathrm{u}$ observarse los tratamientos periodísticos en determinados temas sensibles y en general, así como velar los intereses del público ante un medio, atender sus quejas y sugerencias particulares por la cobertura mediática.

Como parte de las funciones Ombudsman del Lector, la investigación propone:

1. Garantizar transparencia, buen trato periodístico y apego a la ética en cada medio de comunicación social, específicamente en cada producto periodístico.

2. Atender y realizar la respectiva investigación acerca de las quejas de los lectores de los medios de comunicación social del país, en aras de mantener el adecuado equilibrio informativo y ético en la cobertura noticiosa.

3. Sugerir cambios o proponer soluciones para remediar situaciones en las que sean afectadas las poblaciones lectoras por determinada información publicada por los medios de comunicación.

4. Gestionar la capacitación profesional constante en los y las periodistas costarricenses, en especial, en temas sensibles para la sociedad.

5. Considerar la opinión de las poblaciones lectoras respecto del ejercicio periodístico nacional.

6. Garantizar el debido derecho de respuesta o contestación de aquellas personas que, al ser protagonistas de la noticia, sienten la necesidad de referirse a las publicaciones que les atañen directamente.

7. Tender un canal cercano de comunicación entre instituciones públicas, organizaciones sociales y la prensa costarricense, en aras de mejorar los mecanismos en el abordaje informativo.

8. Procurar que sus posiciones guarden siempre el debido 
proceso para mantener su autoridad moral y la credibilidad ante la población.

9. Velar por que las imágenes y otro tipo de material de apoyo visual al texto informativo cumplan con las características para evitar la creación de etiquetas sociales o estereotipos.

10. Revisar permanentemente del lenguaje periodístico utilizado en los medios de comunicación social costarricenses.

Tomando en cuenta la información recabada en la cita con las mujeres privadas de libertad, se presentan las siguientes recomendaciones para la cobertura de los sucesos y para la prensa en general, en su gestión como actor formador de opinión pública en una sociedad. Es importante detallar que estas se presentan desde dos perspectivas vitales: la redacción periodística y la gestión del medio de comunicación como tal.

Desde la redacción de notas periodísticas (periodista), esta investigación propone:

1. Evitar el uso de palabras que atenten contra la integridad de las personas protagonistas de la nota roja. En ocasiones el uso de palabras o sinónimos afines al delito cometido afectan la moral de quienes son identificados con estos calificativos. En este daño moral también son afectadas sus amistades y familiares.

2. Releer las informaciones escritas de manera que sea posible la detección de palabras que ofendan a la protagonista de la nota roja y a los mismos lectores.

3. Dar un seguimiento a la noticia de forma que permita retomar aspectos que por la premura de la cobertura periodística no fueron

bien desarrollados en la publicación.

4. Tratar de consignar en las informaciones la versión de las personas implicadas en el delito. De esta forma, se les presenta la oportunidad de descargar sus propias emociones y se cumple con el equilibrio informativo que debe existir en la noticia, sea esta televisiva, escrita o radiofónica.

5. Solicitar el permiso correspondiente para el uso de imágenes de las personas detenidas, trasladas a prisión o enjuiciadas. Muchas han sido las imágenes que han sido publicadas sin el menor consentimiento y en circunstancias nada favorables para estas personas.

6. Utilizar el mismo estilo de redacción que emplean para publicar la nota tradicional. Por el tipo de información, la nota roja es acompañada muchas veces de una redacción informal, poco seria, con un lenguaje coloquial, lo que genera en el público sentimientos adversos.

7. Evitar las interpretaciones al escribir una nota de sucesos. Cuando se basa el reporte en una redacción interpretativa, se corre el riesgo de producir un impacto sensacionalista.

8. Realizar una exhaustiva investigación de los hechos, en aras de presentar el acontecimiento sin sesgos deliberados.

9. Detallar la condición judicial de la persona incriminada. Las diligencias policiales se ejecutan 
por diferentes razones, no necesariamente por haber cometido un delito; entonces, es importante especificar las condiciones penales de la persona implicada.

10. Recordar que el (la) periodista debe informar; no es un escritor de novelas policiales, por lo cual debe alejarse de modelos literarios que presenten la historia como una novela.

11. Tener presente que la persona periodista no cumple rol de juez, fiscal o abogado defensor. La condición de la persona protagonista de la nota solo compete a las autoridades judiciales con su respectiva presentación de pruebas y demás evidencias.

12. Reflexionar alrededor de la generación de estereotipos que pueden estar presentes en sus informaciones.

\section{Identificar el género periodístico} idóneo para desarrollar la cobertura de sucesos. Expertos comunicadores sugieren que la crónica tiene la versatilidad para presentar la nota roja sin caer en la transformación del hecho en una novela espectacular.

Desde la gestión de la prensa escrita como formador de opinión pública, esta investigación propone:

1. Impulsar la elaboración de un manual especial para la cobertura del suceso, que incluya normas de recopilación de la información, de redacción y elementos visuales.
2. Realizar con periodicidad actividades de consulta con sus lectores(as), de forma que sea posible conocer sus percepciones, recomendaciones o comentarios relacionados con la cobertura periodística que realizan sus profesionales ante determinados hechos, en especial, los sucesos.

3. Establecer un código deontológico que recopile los valores y las normas del medio de comunicación en aras de crear una normativa de lo ético que regule la profesión de sus periodistas.

4. Ejecutar estudios de audiencia orientados a conocer sus deseos informativos, lo que les permite reorientar sus coberturas $\mathrm{O}$ evaluar su accionar en las diferentes secciones informativas del medio.

5. Impulsar la capacitación de sus periodistas en foros nacionales e internacionales que les posibilite la actualización profesional en la cobertura noticiosa.

6. Equilibrar la cantidad de informaciones nacionales y de otra índole con la de sucesos, pues en las ediciones noticiosas se abusa de la oferta de sucesos entregada al público.

En síntesis, el periodismo nacional requiere una etapa de reflexión en la que sea revisado el accionar de los(as) periodistas de sucesos en la cobertura de la nota roja. 


\section{Referencias}

Arguedas, C. (4 de noviembre del 2013). Reos recién salidos de prisión mataron 32 personas en 2 años. La Nación. Recuperado de https://www.nacion.com/suceso $\mathrm{s} /$ crimenes/reos-recien-salidosde-prision-mataron-32-personasen-2anos/RAXC6ZSGLJEIZDPJFW BFSZ34UM/story/

Agencia/Redacción (13 de agosto del 2013) Privadas de libertad del Buen Pastor celebrarán día de la madre en medio del hacinamiento. CRHoy. Recuperado de https://archivo.crhoy.com/priva das-de-libertad-del-buen-pastorcelebraran-dia-de-la-madre-enmedio-delhacinamiento/nacionales/

Delgado, D. (24 de agosto del 2013). Jueces penales rechazan visitar cárceles por falta de seguridad. $\mathrm{La}$ Nación. Recuperado de https://www.nacion.com/suceso s/judiciales/jueces-penalesrechazan-visitar-carceles-por-faltade-

seguridad/H7Z2UPU2KZHXVD APYJW4M35QNQ/story/

Delgado, D. (16 de setiembre del 2013). 33 convictos fueron asesinados al poco tiempo de dejar la cárcel.. Recuperado de https://www.nacion.com/suceso $\mathrm{s} /$ seguridad/33-convictos-fueronasesinados-al-poco-tiempo-dedejar-lacarcel/LUFWSMJRKRB6DELX JJBFKBKTAA/story/

Delgado, D. (30 de octubre del 2013). $73 \%$ de presos elegidos para dejar cárceles son asaltantes. La Nación. Recuperado de https://www.nacion.com/suceso s/seguridad/73-de-presoselegidos-para-dejar-carceles-sonasaltantes/37FVGJUBPFA7TFC H4TSMCAQUKU/story/

Delgado, D. (9 de diciembre del 2013). Eugenio Polanco: 'La mayoría tendrá sed de venganza social'. La Nación. Recuperado de https://www.nacion.com/suceso s/seguridad/73-de-presoselegidos-para-dejar-carceles-sonasaltantes/37FVGJUBPFA7TFC H4TSMCAQUKU/story/

Delgado, D. (19 de diciembre del 2013). Defensoría alerta que menores presos son quemados y golpeados por otros reos. $\mathrm{La}$ Nación. Recuperado de https://www.nacion.com/suceso $\mathrm{s} /$ seguridad/defensoria-alertaque-menores-presos-sonquemados-y-golpeados-por-otrosreos/AUCP3LOHEJGTJGATU BEQVJ7CRE/story/

Delgado, D. (20 de diciembre del 2013). Intimidación y tortura imperan entre reos en cárceles juveniles. La Nación. Recuperado de

https://www.nacion.com/suceso s/seguridad/intimidacion-ytortura-imperan-entre-reos-encarcelesjuveniles/RAGKORZWCBB6H L4QBLMHRI5MU4/story/

Estrada, M. (4 de junio del 2013). Regalan libertad a 3 mamás reclusas. Diario Extra. Recuperado de https://www.diarioextra.com/N oticia/detalle/150275/regalanlibertad-a-3-mam-s-reclusas

Estrada, M. (6 de agosto del 2013). Reclusas pagan $\$ 50$ mil por litro de Cacique. Diario Extra. Recuperado de 
https://www.diarioextra.com /Noticia/detalle/139706/recl usas-pagan-50-mil-por-litro-decacique

Estrada, M. (10 de agosto del 2013). Puñales viajan entre nalgas y papel carbón. Diario Extra. Recuperado de https://www.diarioextra.com /Noticia/detalle/145973/pun ales-viajan-entre-nalgas-ypapel-carbon

Estrada, M. (14 de agosto del 2013). Matan reo para no pagarle deuda. Diario Extra. Recuperado de https://www.diarioextra.com /Noticia/detalle/50217/mata n-reo-para-no-pagarle-deuda

Estrada, M. (31 de agosto del 2013). Reos premian gatos con gallo pinto. Diario Extra. Recuperado de https://www.diarioextra.com /Noticia/detalle/170327/reospremian-gatos-con-gallo-pinto

Estrada, M. (12 de octubre del 2013). Motines y agresiones ponen cárceles color de hormiga. Diario Extra. Recuperado de https://www.diarioextra.com /Noticia/detalle/216027/moti nes-y-agresiones-ponencarceles-color-dehormiga\#: :text=Los $\% 20$ moti nes $\% 20 y \% 201$ as $\% 20$ constantes ,las $\% 20$ diferentes $\% 20 \mathrm{c} \% \mathrm{C} 3 \%$ A1rceles\%20del\%20pa\%C3\% ADs.

Recibido: 11 de abril de 2019

Aceptado: 21 de noviembre de 2019
García, M. y García, L. (2008). La recepción de la imagen de las mujeres en los medios: una aproximación cualitativa. Nueva época, núm. 10, juliodiciembre, 2008, pp. 111-128. ISSN 0188-252x. Barcelona, España.

Genara, M. (2009). Estudio sobre la imagen de la mujer peruana en la publicidad gráfica del suplemento sabatino Somos. Perú. Recuperado dehttp://udep.edu.pe/comuni cacion/rcom/pdf/2009/Art14 5-166.pdf

Martín-Barbero, J. (2003). De los medios a las mediaciones. Bogotá. Convenio Andrés Bello.

Miranda, H. y Rodríguez, O. (22 de mayo del 2013). Mujer que pide indulto por matar a bebé: 'Yo no estaba bien'. La Nación. Recuperado de https://www.nacion.com/suc esos/mujer-que-pide-indultopor-matar-a-bebe-yo-no-estababien/4U3MIYS5GBG6HCMS XLMX5Z4PIM/story/

Murillo, A. (16 de setiembre de 2013). Mujer indultada: 'En la cárcel hay mucha droga'. Periódico La Nación. Recuperado de https://www.nacion.com/elpais/mujer-indultada-en-lacarcel-hay-muchadroga/23PL4WHVJRBZLCK TG2RZMBCY6A/story/ 